\title{
Exposures: Nancy and Heidegger on Community
}

\section{Andrea Rehberg}

To cite this article: Andrea Rehberg (2004) Exposures: Nancy and Heidegger on Community, Journal of the British Society for Phenomenology, 35:3, 228-245, DOI: 10.1080/00071773.2004.11007444

To link to this article: https://doi.org/10.1080/00071773.2004.11007444

\section{Published online: 21 Oct 2014.}

Submit your article to this journal $\pi$

山 Article views: 44 


\section{EXPOSURES: NANCY AND HEIDEGGER ON COMMUNITY}

\section{ANDREA REHBERG}

In the spatial and temporal dislocations wrought by cosmopolitan existence, a new sense of the self emerges, not that of a foundational 'I' or a self-present subjectivity, but a new authenticity, borne out of a 'constitutive' withdrawn collectivity:

Yesterday I was in Amman, sitting in the Roman theater, and I had an odd sensation. I don't know if I can describe it but I think I perceived solitude as a collection of things rather than an absence of things. Being alone has components. I felt I was being put together out of these nameless things. This was new to me. Of course I'd been traveling, running around. This was the first quiet moment I'd had. Maybe that's all it was. But I felt I was being put together. I was alone and absolutely myself. ${ }^{1}$

This observation, à propos of nothing, is spoken by the protagonist and occasional first-person narrator of Don DeLillo's novel The Names. It is quoted here because it seems to me to resonate with a number of the key themes in the two texts under discussion in this paper, Jean-Luc Nancy's 'The Inoperative Community' and Heidegger's Being and Time ${ }^{2}$. These themes are: the unsayable as constitutive ("these nameless things"); the plenitudinous absentiality of being-with or community ("I perceived solitude as a collection of things"); being brought before one's own existence ("I was alone and absolutely myself'); the 'I' of this existence as not simply given, let alone as underlying substance, but as concomitant with community ("I felt I was being put together"). ${ }^{3}$

Talk of 'community' is all around, both in more or less unthinking public discourses, including, for instance, those of politicians or journalists and, at the other extreme, in the philosophical writings of many of the major thinkers of our time. But what does 'community' mean, what are its implications and ex-plications? This is not to ask what we might mean by the word 'community', since it has no single or univocal meaning underlying all the discourses which it informs. Rather, it is to ask how a certain sense of 'community' can infiltrate our thinking and our existence, since it always comes from outside, the outside of identities, concepts, or ideas, and the outside of projects, works, or mere acts. And again, many genres (of 'writing') are capable of demonstrating these processes of infiltration, such as those of art or literature, and also those of sociology or political philosophy in the narrow sense. But whilst perhaps it cannot claim any exclusivity as point of entry into this issue, it nonetheless seems to me that few essays attain such sustained philosophical rigour as Jean-Luc Nancy's 1986 piece 'The Inoperative Community'. By way of an intermittent reading 
of selected passages from Bataille's Oeuvres Complètes on community and related topics, Nancy gestures ${ }^{4}$ towards his own understanding of the elusive term 'community', whilst this is also inevitably shaded by the Heideggerian provenance of much of his thinking.

The following does not attempt a general overview or an explication of Nancy's text, nor a comprehensive exploration of the theme of community, not least because such attempts seem to me to be futile, given that they may result in the closing down of the textuality of the text, quite apart from which they would be the hermeneutic equivalent of what Heidegger calls 'leaping in'..$^{5}$ Instead, this paper aims to suggest a more or less 'subterranean' connection between elements of Nancy's thought on community and certain structural moments in Being and Time. Hence it is a matter of setting up the encounter between the (for this project) relevant strands of these two texts. This paper merely seeks to project a movement from 'IC' to BT and back, so that, in this encounter between the two texts, a thought may arise which is not to be found in either text by itself but which can be shown to belong to either text when it is exposed to the other. We will see that this hermeneutic approach closely mirrors the substance of Nancy's thought of community. This is also to say that this paper attempts to carry out something like a double immanent critique in which 'IC' opens up certain possibilities of rereading BT and in which this re-reading in turn stimulates reconsideration of 'IC'. Hence in a minor hermeneutic way, the present endeavour seeks to enact the very relationality central to both BT and 'IC'.

In the first section I attempt to show the movement of thought by which Nancy approaches the 'ground' of community as being-in-common and, in turn, its withdrawn ontological fundament, namely the finitude(s) of being, foremost among them the finitude of the always other (including myself). This then calls for a reconsideration of certain moments in BT concerning being-towards-death, and the scope of the disclosive force of this most profound of relationalities. This discussion, which is central to the present paper, takes up sections $I I$ and $I I I$. Lastly, a very brief section aims to explore the limits and openings of Nancy's thought of community.

"Community is calibrated on death as on that of which it is precisely impossible to make a work" ( IC' 15)

As already stated, the aim of this section is not to reconstruct the various conceptual and philosophical moves through which Nancy chisels out the sense of the community which he takes to be the 'always already' of our social existence ${ }^{6}$. Instead it only aims to get to the point where 'IC''s only very brief explicit engagement with BT can be seen to be inevitable - and then to go a little further. Nancy's aim in 'IC' may be broadly stated as the 
search for a new sense of the political, infused with the thoughts of difference ${ }^{7}$, rather than mired in adherence to the metaphysics of presence, identity, and subjectivity, i.e., in humanism. This search - apart from its strictly philosophical exigency - is equally born out of a profound dissatisfaction with the ability of political projects or programmes to alleviate the conditions under which the greater part of contemporary humanity subsists, as with the moribund state of many current political philosophies, especially those of a 'communitarian' bent. The failure of communism in both of these two categories further helps to focus Nancy's thought. As he puts it, "(Western) philosophy's political programs have come to a close" (IC xxxviii). Nor does Nancy succumb to the lure of what he calls a "broadly pervasive democratic consensus" because he realises that this consensus only "seems to make us forget that 'democracy'...serves only to assure a play of economic and technical forces that no politics today subjects to any end other than that of its own expansion. A good part of the human community is paying the price for this." (IC xxxvii).

As a first strategy for avoiding the effacement of difference in a thought of the political, Nancy mobilises Heidegger's notion of ontological difference for a reconception of what marks out 'the political' (le politique) from politics (la politique) (IC $\mathrm{x}$ ), such that the former designates the ontological, the latter the ontic pole of their differing. By way of a preliminary delineation of the former Nancy states that "the political is the place where community as such is brought into play" (IC Preface, xxxvii), and as "the moment, the point, or the event of being-in-common" (IC Preface, $\mathrm{xl}$ ). As with Heidegger's conception of the ontological difference, so for Nancy too, the attestation of it calls forth finite being which 'gives' this differing through the play of its advent and withdrawal. Nancy calls the play of this finite being community or being-in-common. It 'is' the prototranscendental, if historical, 'condition of possibility' of our shared social existence. The movement of its withdrawal articulates itself, among other things, in such a way that community resists thought. Nancy signals this when he writes that "community has still not been thought" ('IC' 26), and that "it is a matter...of thinking community, that is, of thinking its insistent and possibly still unheard demand." ('IC' 22). That this thought, in one of the oscillations within ontological differing, withholds itself is also, I take it, one of the reasons for the apparent obstacles to broaching the topic, to entering the thinking of community, which Nancy's text also enacts, and why there are several provisional points of entry, often surrounded by signs of deferral and expressions of reservation.

For reasons of space I must all but circumvent a discussion of what, for Nancy, community is not. Suffice it to say that the constant threat of the eradication of difference, against which both the ontologically thought 
political as well as ontic politics must strive to hold open a space of irreducibility, is also perceived by Nancy to lurk in the "community that becomes a single thing (body, mind, fatherland, Leader..." (IC xxxix), to which innumerable instances could be added, such as State, nation, party, society, family, etc. Each of these implies "a higher form of substance or subject taking charge of the limits of separate individualities" ('IC' 27), whereas being-incommon is not to be conceived as "a substance uniformly laid out 'under' supposed "individuals"" or "uniformly shared out among everyone" indifferently (IC xxxvii). In short, community does not have the character of hypokeimenon, whether as (a higher form of) subject or substance, which is also why it "cannot be presupposed" but instead "only exposed" (IC xxxix).

This brings us to the question of why Nancy insists on community being désoeuvrée, and this question takes us to the heart of the problematic to be developed here. Although the 'inoperative' character of community is its most crucial feature, in this paper I will only discuss what I take to be the most salient aspects of this feature. The non-substantiality of community mirrors the non-substantiality of that being which, with the demise of the metaphysics of presence, we no longer think of as the subject. And just as community cannot be presupposed, neither can the subjectivity of that being - which Heidegger names Dasein - any longer be presupposed. The reasons for the unavailability of subjectivity are of course multiple and historically complex but they centre around the insight into the essential finitude of this being, Dasein. And again, the forms which Dasein's finitude takes are multiple (among them world, language, thinking), but the most nonnegotiable form of its finitude lies in its temporally finite existence, its death (as well as its birth). To the finitude of Dasein there answers the finitude of being, such that each consigns the other to its role. Dasein and being reciprocally need and need to affirm each other, and this (in both senses of the word) finite reciprocity is revealed to Dasein through its death (see sections $I I$ and $I I I$, below, for a fuller discussion of this).

The Heideggerian point of departure for Nancy's reflections on community is encapsulated in the insight that "Being 'itself' comes to be defined as relational, as non-absoluteness, and...this is what I am trying to argue - as community." ('IC' 6). If being, or being-in-common (as ontologically conceived community) is not an underlying substance, neither is it the product of, for instance, a sublation in which its members or elements are caught. Neither being nor being-in-common are produced in the (secondary) work of its (primary) constituents, for if this were the case it would reinforce the subjectivity of these primary constituents. The notion of an operative community, a community produced by and as work, would constitute an inauthentic relation to the metaphysics of subjectivity. It would still adhere to the representational model according to which pre-given, 
primarily isolated, self-present individuals only subsequently, secondarily, 'combine' by means of an alleged 'intersubjectivity' to produce community. Instead it is crucial to maintain that "It is not a matter of making, producing, or instituting a community." ('IC' 35), and that

Community necessarily takes place in ... 'unworking', referring to that which ... withdraws from the work, and which, no longer having to do either with production or with completion, encounters internuption, fragmentation, suspension. ('IC' 31).

In this sense, and no doubt contra Hegel, community is unworking. Nancy writes that,

... community cannot arise from the domain of work. One does not produce it, ... one is constituted by it as the experience of finitude. Community understood as a work or through its works would presuppose that the common being, as such, be objectifiable and producible (in sites, persons, ... discourses, institutions ... in short, in subjects). ('IC' 31 ).

But being-in-common is not just nothing (even if it is not some thing (res) either), just as human being as Dasein is not nothing, even though the nothing of its existence (death) is that which discloses its existence to it. In fact, it is this very insight, adapted from BT, which is, I believe, centrally formative of Nancy's notion of the unworkable nature of community when he says that one is constituted by it as the experience of finitude. The point here is that whilst my finitude has this disclosive capability, the death towards which I am is strictly inoperative in my existence and cannot be the object of my operations in any meaningful way. Parallel to this, it is the death of others or, to be more precise, the possibility of this other nonexistence, which discloses being-in-common to those beings who are constituted by it.

The inoperative modes of community are sheltered in the death of the other but "Community no more makes a work out of death than it is itself a work" ('IC' 14), on which Nancy elaborates by writing that

... it is in the death of the other...that community enjoins me to its ownmost register, but this does not occur through the mediation of specular recognition. For $I$ do not recognise myself in the death of the other - whose limit nonetheless exposes me irreversibly. ('IC' 33).

In this thought of community, in other words, death is not put to work, it is neither sublated nor realised nor even yet made the object of a presentation or representation. Hence this death is also exempt from (Hegelian) processes of recognition. On the contrary, it is a matter of an exposure to the fragmentation which occurs around this limit. As Nancy puts it,

... the origin of community ... is nothing other than the limit: the origin is the tracing of the borders upon which or along which singular beings are exposed ... I do not rediscover myself, nor do I recognise myself in the other: I experience the other's alterity, or I experience alterity in the other together with the alteration that 'in me' sets my singularity outside me and infinitely delimits it. ('IC' $33 \mathrm{f}$ ).

Hence 'community' at bottom names the ineluctable 'double exposure', or finite transcendence, which brings me before the other by bringing me before 
the death of the other and vice versa and, co-originally, before my own death, in the exposures to which the meaning of 'our' being lies concealed. So much for the, albeit very brief, exposition of the privative mode in which community reveals itself, and which is signalled by its designation as inoperative.

\section{II}

"Death ... is the true community of I's that are not egos" ('IC' 15)

As stated above, the assumption of subjectivity, whether in the singular or the plural, as a basis for community has become, to say the least, problematic, given the critique of substance and subject developed into a more or less systematic Destruktion of metaphysics by Heidegger. This is to say that the theoretical discourses based on the assumption of a Cartesian cogito have been thoroughly disrupted by a fundamental ontology in concert with an analytic of the existence of Dasein, as carried out in BT $^{8}$. What is most important for our purposes here is that the analytic of Dasein shows that human being as Dasein does not first and foremost relate to its world in a theoretical manner but instead finds, and indeed loses, itself in its world; and that it does so as pre-theoretical projects and as an entire pre-cognitive structure of involvements with 'its' world, which of course never belongs to it in any actual possessive sense. Dasein as a structural phenomenon is not, intellectually, rationally or intentionally present to itself but instead always already ontologically beyond itself. As such it is out-standing or ecstatic. But importantly, the transcendence of Dasein charted in BT is that of finite being.

Division One of BT thematises the structures of Dasein's being-in-theworld which as a whole turned out to be 'care', or "ahead-of-itself-Beingalready-in-(the-world) as being-alongside (entities encountered within-theworld)." (BT $\S 41,192$ ). But as being-in-the-world Dasein exists for the most part in the mode of inauthenticity and thus as "less than a whole [als unganzes]." (BT $\S 45,233$ ). Hence a complete phenomenological interpretation of Dasein has to show the primordial ontological ground which makes both inauthenticity and authenticity possible for Dasein. Preparatory to this, Heidegger raises the question of Dasein's potentiality-for-being-awhole (ibid.). He writes

As long as Dasein is, there is in every case something still outstanding, which Dasein can be and will be. But to that which is thus outstanding, the 'end' itself belongs. The 'end' of Being-in-the-world is death. This end, which belongs to the potentiality-for-being ... limits and determines in every case whatever totality is possible for Dasein ... as something of the character of Dasein, death is only in Being towàrds death. (BT 233f).

It is this dual search for the ontological fundament of Dasein and its complete phenomenological interpretation which opens on to, and is opened up by, the understanding of temporality as the "primordial ontological basis 
for Dasein's existentiality" (BT 234). And so the structures of Dasein which the analytic of Division One uncovered, since they "are all to be conceived as at bottom temporal" (BT $\S 61,304$ ), require a repetition, in Division Two, on the grounds of the temporality of Dasein (ibid.), if the being of this being is to be "brought to light...in its possibilities of authenticity and totality" (BT 233).

What 'is' death for Dasein? What does the existential analytic discover about it? Heidegger offers the following 'Preliminary Sketch' of it':

With death, Dasein stands before itself in its ownmost potentiality-for-Being. This is a possibility in which the issue is nothing less than Dasein's Being-in-the-world. Its death is the possibility of no-longer-being-able-to-be-there ... Death is the possibility of the absolute impossibility of Dasein. Thus death reveals itself as that possibility which is one's ownmost, which is non-relational, and which is unovertakeable [unüberholbar]. (BT § 50, 250, translation modified ${ }^{10}$ ).

We will have occasion to return to this passage. For the moment suffice it to say that Dasein is brought before the limit of its existence with death. There is no possibility within each Dasein which exerts a greater power over it, or indeed is more certain, than its death. How is Dasein related to its own death? Above all else, it is not related to this utmost possibility of its being in any theoretical or explicit manner (BT 251). Instead, and in strictly ontological terms, its thrownness into death reveals itself to Dasein in the disposition (Befindlichkeit) of anxiety (Angst) (ibid.). Disposition, here as anxiety, does not signify any kind of psychological interiority, mental state ${ }^{11}$ or existentialist subjectivity. It is instead a way in which Dasein's existence is disclosed to it impersonally, pre-intellectually, and non-subjectively. In anxiety Dasein becomes open to and for its own utmost possibility of being. But just as the disclosiveness of disposition has to be delineated against all intellectualist misinterpretations, so the privileged disposition of anxiety has to be carefully distinguished from its innerworldly, ontic variant, fear. "The 'whereof' [das Wovor] of anxiety is Being-in-the-world as such." (BT § 40, 186, translation modified), whereas the 'whereof' of fear is always something which Dasein encounters, in whatever manner, in the world. Whereas anxiety, in that it is directed to nothing ${ }^{12}$, is an authentic disposition, fear is an inauthentic disposition (c.f. also BT $\S 68$ b), 341-4), since it merely holds Dasein in, or binds it to the world, rather than freeing it for that which 'gives' world in its withdrawal, namely being.

But it must be emphasised that death is not a possibility that merely occurs at the end of Dasein (BT $\S 62,306$ ). In its Being-towards-death Dasein is always ahead-of-itself (BT $\S 52,259$ ). It is in this possibility that Dasein is temporally ecstatic, that is to say, authentically ecstatic as standing out into its most extreme possibility of not-being. In its Being-towards-death, given by the absolute ineluctability of the nothingness of death, Dasein is both irretrievably ahead of itself and thrown back to itself as its 
insurmountable, utmost possibility of being. As its death, which is ontologically prior as the always already of Dasein, its essence as ecstatic temporality, is revealed. Or, as Heidegger puts it, "authentic Being-towardsdeath is anticipation." (BT $\S 61,301 \mathrm{f}$ ), where anticipation (as opposed to ontic expecting) means letting death be as possibility, i.e., without attempting to actualise it (BT $\S 53,262$ ). What is laid bare here is the temporal-existential structure of Dasein, in which

Dasein can ... come towards itself in its ownmost possibility...and it can [let] itself come towards itself - in other words, [exist]. This letting-itself-come-towards-itself ... is the primordial phenomenon of the future as coming towards. (BT $\$ 65,325$ ).

Dasein does not simply come to an end at which its existence ceases but, much more fundamentally, "it exists finitely" (BT 329). That is to say that the very possibility of its existence is opened up for it by the finitude of this existence. It is only as finite that Dasein exists. One might say that its existence is the gift of death.

What has emerged so far in this brief exposition of some of the central insights of BT regarding this issue is the ontological significance for Dasein of its being-towards-death which is disclosed for it in the disposition of anxiety, and to which it is related in the temporal structure of anticipation. What has thus emerged for our current project, as a first, preliminary step, is the future-oriented, pre-theoretical force, namely the anxiety in which my death is disclosed to me, and which can, in the next stage of the present project, be taken further to elucidate its relevance for a possible thought of community, such as Nancy envisages. But, unsurprisingly (as it will turn out), this thought really only opens up in the aporias of Heidegger's phenomenology of Dasein. Hence in the next section it will become necessary to revisit some of the passages already explored, and some as yet undiscussed, in order to find a productivity in the unsaid of Heidegger's text which unsaid, much more than its said, holds the promise of an ontologically founded possible thought of community.

\section{III}

“Dasein's 'being-towards-death' was never radically implicated in its being-with - in Mitsein - ... it is this implication that remains to be thought" ('IC' 14) ${ }^{13}$.

BT does of course gesture towards Dasein's relation to other Dasein in the structure of being-with (Mitsein) (BT §§ 25-27). But the others with whom Dasein is in its being-with are assigned the average character of the 'they' (das Man), the neuter that designates not this or that other, not some others, and not the sum of all others (BT $\S 27,126$ ). In short, for Heidegger, others as the 'they' are undifferentiated and mark an inauthentic mode of my Dasein, insofar as 'they' hinder me from taking over my ownmost potentiality-for-being. One possible trajectory following on from this could 
be a more developed reading of the full ontological dimensions of beingwith. But Nancy's concerns point to the question of how Mitsein and beingtowards-death are related and this is what we will go on to examine.

The previous section attempted to show how Dasein is exposed to its ownmost potentiality-for-being by being brought before its own death in its being-towards-death, how this is disclosed to it in anxiety and how Dasein takes over this utmost possibility in anticipation. The central issue for this section, which must now be examined, is whether being-towards-death, which throws Dasein back on its own existence and thus opens it up for Dasein to take over, can also, as the death of the other, be revealed as the ontological ground from out of which the existence of the other is opened to and for Dasein, and can thus found their, our, being-in-common.

The ontological structure which is sought here would have the character of being-towards-the-death-of-the-other, in which their finitude would leak into my potentiality-for-being and open up their existence for mine and vice versa, so that the groundless ground of our common mortality, our common finitude, would expose us to the possibility of shared existence ${ }^{14}$. This ontological structure would be revealed to me in the disposition of anxiety in the face of the death of the other which, no less than my anxiety in the face of my own death, brings me before my own existence and, crucially, exposes me to the possible silence from out of which community can speak; and it would demand to be taken over by me in an anticipation which encounters the stark possibility of the not-being of the other. But of course it is not sufficient or even entirely accurate to say that these moments are being 'sought', as if it were a question of intentionally trying to capture an elusive prey. It is of course only possible to move towards this thought because it calls us forth and calls out to be articulated. In other words, here too hermeneutic circularity would make it possible to encounter the disclosiveness which comes towards me as the death of the other. As a way into this problematic, we will first of all critically examine some of the comments on the death of the other in BT in order to see whether this other death offers any resources for thinking this issue but, as has already been intimated, in particular with a view to its productive aporias.

At first it would appear that there is an easy access to the death of the other, when Heidegger writes that "Dasein can...gain an experience of death, all the more so because Dasein is essentially Being with Others." (BT $\S 47,237$ ). This appears to suggest that I can have a first access to death via being-with, and through witnessing the death of the other. But it must be remembered that we are not here concerned to discover how Dasein can have access to its own mortality, but whether the mortality of the other can disclose community, rather than my own existence. But Heidegger goes on to say that in fact the dying of others is "not something which we 
experience in a genuine sense." (BT 239). In this statement, as in many others of this kind, 'experience' is a very problematic, not to say misleading, term, since it must be remembered that I also do not in any immediate way experience my own death, which 'is' instead something like a temporal horizon for my existence or, formally speaking, something like the condition of possibility of experience. In addition to this problematic point, another issue here is that Heidegger's characterisation of the dying of others maintains a silence about its inherent connection to being-towardsdeath. This is all the more remarkable given that just two paragraphs later Heidegger stipulates "Let the term 'dying' stand for the way of Being in which Dasein is towards its death." (BT $\S 49,247$, emphases in the original). The point here is that being-towards-death must be understood as the ontologically disclosive possibility of my Dasein and, I want to suggest, can be unfolded, co-originally, in the ontologically conceived death of the other ${ }^{15}$. If left to stand in its current form, it is true to say that the dying of the other cannot be experienced, but then neither was the experience of dying ever the issue for Dasein and so fundamental ontology seems to miss its mark at this point.

Throughout these passages (especially in $\S 47$, but also in $\S \S 51$ and 52) Heidegger moves very swiftly from the death of the other to the structures of concern which unfold around the dead other, which cannot really be the issue, just as dead Dasein was not the issue. The death of the other is only discussed by Heidegger insofar as it actually occurs, as it has already become the dead other. But the structure which I attempt to trace here would concern the death of the other as the ontological possibility that has meaning for us. And it is this possibility which BT does not address.

In Heidegger's account of it the death of the other has no disclosive force. This is made explicit in the comment that in suffering the loss of another, "we have no access to the loss-of-Being [Seinsverlust]", especially since this loss-of-Being is characterised as that which "the dying man "suffers"" (BT § 47,239 ). Thus there is no scope here for the loss-of-being, which occurs in the death of the other, to become disclosive of the withdrawal of being which in each case gives the possibility of existence, hence also of our common finite existence. To be generous to Heidegger, it could be said that the effort to allow the overall ontological structure of Dasein to show itself, first in its being-in-the-world and secondly, in the repetition, as being-towards-death, did not leave much room for the detailed analysis of the positive aspects of being-with, foremost among them the other's mortality as the basis of our being-in-common. But given Heidegger's frequent attacks on the artificial and merely ontic distinction between the theoretical and the practical orientation of philosophy, as well as the stated ambition to present Dasein's structure as a whole, these lacunae perhaps weigh more heavily than that. At 
one such moment, when the overarching concern seems to be that of delineating Dasein's singular existence, we read

the suggestion that the dying of others is a substitute theme for the ontological analysis of Dasein's totality ... rests on a presupposition which demonstrably fails altogether to recognize Dasein's kind of Being. This is what one presupposes when one is of the opinion that any Dasein may be substituted for another at random, so that what cannot be experienced in one's own Dasein is accessible in that of a stranger. (BT 239).

What is interesting here, to begin with, is that it is the death of a stranger, not of a friend or relative, that is mentioned. Does this imply that for Dasein every other Dasein is a stranger, even a relative or a friend? But of course, again, the real issue is that Heidegger overlooks a possibility which is very different from the one he considers here, namely Dasein's substitutability. That other possibility would not attempt such a substitution but instead, in letting the death of the other, as well as my own death, come towards me, it would understand that they or, more precisely, the shared manner of their anticipation, are not incompatible or mutually exclusive. Furthermore, far from threatening my singular existential project, that other possibility would see it as also based on that other death, in which being futurally withdraws between us, the other and $I$, and thus gives our being-in-common, the other and I. As if substitutability were the only issue, though, Heidegger declares, "No one can relieve the other of his dying. [Keiner kann dem Anderen sein Sterben abnehmen $]^{16}$." (BT 240). No doubt, death (not dying) is essentially mine but as that of the other, and as such beyond relief, it is also the ground of our being-in-common.

As Heidegger states, "The essence of Dasein lies in its existence." (BT § 9, 42). That is to say that the being of this being lies in its "there', beyond itself, in the structural whole of its finitude, in its being-in, being-with, and beingtowards, whence it is thrown back on itself in its projections. Throughout BT the analytic of Dasein is rigorously sustained. Yet when it comes to the ontological foundation of being-with, the rigour of the analysis diminishes, so that the ground of the possibility of what may be called being-between-Dasein remains concealed. Could this be because the being of this between-us has the most primordial constitution of all the finite articulations of being? And is it perhaps as such the unsayable ground of all the possible 'there' of beingthere? Is it indeed the case, as a recent reflection on these issues has it, that we are 'the community of those who have nothing in common' 17 , precisely the nothing of our existence, your death and mine? It is in the ineluctable silence which reigns between us, the unsayable as an absolute dissensus, that we are in communion, in community. This is the silent interjection of your death into my existence, the always already nothing of our being-in-common.

Of course it is not possible to relieve the other of their death, nor is it desirable, since any futile attempt at doing so would only propel them (and 
me) towards inauthenticity. But if we are to take seriously the fundamental 'there' structure of Dasein, the possibility of the between-us also needs to be shown in its ontological fundament. The possibility of this is completely rejected by Heidegger, most notably in the following passage (a truncated version of which we saw before) which typifies his stance:

\begin{abstract}
Death is a possibility-of-Being which Dasein itself has to take over in every case. With death, Dasein stands before itself in its ownmost potentiality-for-Being. This is a possibility in which the issue is nothing less than Dasein's Being-in-the-world. Its death is the possibility of no-longer-being-able-to-be-there ... When it stands before itself in this way, all its relations to any other Dasein have been undone. This ownmost non-relational [unbezulgliche] possibility is at the same time the utmost one.

As potentiality-for-Being, Dasein cannot overtake the possibility of death. Death is the possibility of the absolute impossibility of Dasein. Thus death reveals itself as that possibility which is one's ownmost, which is non-relational, and which is unovertakeable [unüberholbar]. (BT $\S 50,250$, bold emphasis added, translation modified).
\end{abstract}

The question here is whether the points made in this passage are an 'accurate' phenomenological presentation of what is ontologically prior in this concealing-revealing. No doubt Dasein stands before itself in its beingtowards-death and is thus sunk into the most profound solitude ${ }^{18}$ from which its projects must arise, just as, undoubtedly, the mortality of the other exerts the same tremendous influence over it. But Heidegger's central claim, which is crucial for our concerns here, namely, "When [Dasein] stands before itself in this way, all its relations to any other Dasein have been undone" simply fails to elucidate the ontological fundament which first of all 'gives' the possibility of this undoing, this non-relationality. To reiterate, it must be the case that there is a prior relation which can be 'undone' for the undoing of it to come about and that it is through the moment of withdrawal in the "es gibt' that the relation can be undone. And the contention is, and has been, that this relation can only arise in the structural moment, unrealised in BT, in which the death of the other comes towards me as being-towards-the-deathof-the-other and hence, in what Nancy calls 'compearance', 'gives' us as both you-and-I and you-and-I ('IC' 29) ${ }^{19}$. Another way of access into this issue would be to draw attention to Heidegger's key statement on this issue, namely that "Death is the possibility of the absolute impossibility of Dasein"20. Formally analogous to this we might say that the death of the other is the ontological possibility of the absolute impossibility of Mitsein, and hence that which primordially gives the possibility of Mitsein ${ }^{21}$.

We saw that in BT the death of the other was reduced to its dying in such a way as to obscure its dimension of being-towards-death; that the experience of this cannot be the issue for Dasein, for the other, or between us; just as it is not that of the dead other; and that neither the substitutability of my death for that of the other nor relieving the other of theirs are what is most fundamentally at stake. And in all these instances the point has been to 
show that the analysis offered by Heidegger always swerves away from the fundamental ontological issues which the complete analytic of Dasein can nevertheless be shown to demand. Symptomatic of these evasions is the astonishing hiatus which speaks so loudly in Division Two of BT, concerning being-with (Mitsein). Division One had considered being-with albeit in the deficient mode of the 'they' (das Man) - in the context of the possibility of being-one's-self (BT $\S \S 25-27$ ). But when it comes to the temporalised repetition of the structures of Dasein, being-with is not thematised at all. Where one might expect such thematising to occur, in $\$ 64$ (on the temporal sense of care and selfhood), there ensues instead a reading of the Kantian paralogisms of pure reason! Although by now this final, most telling and most enormous evasion can no longer be considered surprising, it is surely indicative of the withdrawal of finite being as being-in-common, which has been projected here as being-towards-the-death-of-the-other, from out of which withdrawal even, and especially, the authentic, temporal structures of Dasein can unfold.

But it is important to emphasise that these are not merely formal structures or philosophical abstractions which can be analysed and then indifferently put aside. What has been discussed here must be understood as an attempt at the continuation, albeit by way of an immanent critique, of the phenomenology of human being's essential relatedness. It is the province of philosophical activity to reflect on these phenomena but the implicit assumption is that this reflection is only possible in the first place because as Dasein we are always already exposed to these phenomena. And it was found that there is no more extreme exposure than the anxiety which concerns the death of the other, so extreme in fact that it withholds itself more radically from the possibility of being 'understood' 22 than even my own death. The suggestion has been that it is for this reason that BT is unable to speak of the anxiety in the face of the death of the other, even though, it has been suggested, it is that other death which at bottom gives rise to all the forms of Dasein's relatedness to other Dasein shown there. And just like Heidegger's magnum opus, most of us for most of the time flee in the face of what is nonetheless this most profound truth of human existence - but it is no less of a truth only because it lies concealed in the interstices of our everyday existence and underneath all our more or less rational-subjective planning.

In freeing myself for the thought that I am always already exposed to the death of the other in common with being exposed to my own death, our being-in-common is revealed to me. The anticipatory stance which I have to take up in order to inhabit this advent authentically becomes possible as this co-originary futural arrival of the nothing into our shared existence announces itself. It does so by withdrawing in a deafening silence and I 
respond to it, not by remaining silent in the face of the death of the other, but by withholding any attempt to represent the other to myself or myself to the other. The dissensus for which a space is thus opened is not a mere disagreement, or the inability, in principle, to arrive at it, but the soundless voice of the nothing pervading our being-in-common. Death disappropriates and cannot be appropriated, whether in representation or work. Death is that which opens up the unworking of any possible community and hence, in the utter withdrawal of working, gives the possibility of community ${ }^{23}$.

The structural moments of an ontologically inclined thought of community, revealed in the death of the other, have been shown to be beingtowards-the-death-of-the-other which is inhabited in the authentic stance of anticipation, and which is disclosed in anxiety, the whereof of which is not, in order of ontological priority, the not-being of this or that other but the possibility of the impossibility of all being-with. However remote the possibility of inhabiting my own being-towards-death authentically, the 'possibility of no-longer-being-able-to-be-there', as 'the possibility of the absolute impossibility of Dasein', the end of this Dasein's being-in-theworld is - at least in principle - understandable and thus accessible to Dasein's thought (even though Heidegger considers thinking about death an inauthentic relation to this possibility (BT $\S 53,261)$ ). But the possibility of the impossibility of being-with does not offer itself to Dasein's thought in any concrete ontological sense. 'I' will cease to be (existentially I am the possibility of that impossibility), but for the duration of that possibility, the possibility of the impossibility of being-with withholds itself from understanding (even if and as being-with shows itself in the deficient mode of solitude ${ }^{24}$ ). Does this not suggest that at bottom being-with - as the possibility of the impossibility of being-with - is the absentiality which gives all the elements of the 'there' structure of Dasein, in other words, that beingwith, understood in this dynamic sense, is constitutive of all Dasein? Nancy puts this rather more succinctly when he writes, "Community is given to us with being and as being...At bottom, it is impossible for us to lose community...We cannot not compear." ('IC' 35).

\section{IV}

"Community is revealed in the death of others; hence it is always revealed to others." ('IC' 15)

In section $I$, above, it was emphasised that the inoperative character of community, in Nancy's understanding of it, is its most central feature and that, as being-in-common, it arises out of the unworking which section III, above, showed to lie hidden in the death of the other as (barely) thematised in BT. In a further, final twist, and in lieu of a conclusion - what could there be to conclude when it is a matter of keeping open the play of a mutually 
intrusive alterity? - it will now be a matter of probing the limits of Nancy's conception of this nexus.

To recapitulate, the point is that the reciprocal finitude which reveals itself in the death of the other is not the object of any kind of recuperation or 'conversion', neither recognition, nor sublation, nor transfiguration ('IC' 14f): nothing follows from it, least of all a meaning which could be rescued or expressed in a higher sense of community as the communion of its elements. Nevertheless, the limit that articulates itself as the death of the other "exposes me irreversibly" ('IC' 33) (even though "I recognize that in the death of the other there is nothing recognisable" (ibid.)), and it does so in several intersecting ways. Firstly, this exposure indicates that no retreat to any apparent interiority of subjectivity is possible. The being-in-common which approaches me in the death of the other leaves me stranded in exteriority, in the ecstasis of our shared being. Secondly, this exposure offers nothing to retrieve, no object, product, or work, and it will not be mastered or permit of being incorporated into any project ${ }^{25}$. Thirdly, and here irreversibility connotes inconclusiveness, being exposed to the death of the other can never be completed, I am never done with it and it does not come to rest at any point once and for all, because it must be understood differentially, as a spacing and deferral. In other words, the radical exposure is to an alterity, that Nancy names community, which is itself non-selfcoincident, non-identical and unpresentable. Strictly speaking, there is no community ("community acknowledges and inscribes...the impossibility of community.", 'IC' 15), but its self-differing, its withdrawal, is that which makes possible all being-with. Or, to be more precise, it is the death of the other, towards which I am in an anxiety and anticipation which match those of my own being-towards-death, that marks the rupture of this absentiality into our common existence and makes it possible.

What Nancy gestures towards when he explores the senses of community is, in short, something like an unnameable, as that which withholds itself and which in principle cannot be made present (c.f. 'IC' 22$)^{26}$. Instead, it must be a matter of celebrating the unnameability in and into which we, in world, in language, in death, are woven and of continuing to hold open a space, or spacing, for it.

I found myself studying doors, shutters, mosque lamps, carpets. Surfaces were dense and abstract. Where figural things were present they were rendered as nuances of line or curve, taken out of nature to the level of perfect repetition. Even writing was design, not meant to be read, as though part of some unbearable revelation. I didn't know the names of things. ${ }^{27}$

Bilkent University, Ankara, Turkey 


\section{References}

1. Don DeLillo, The Names, London: Picador, 1999, 162.

2. Jean-Luc Nancy, 'The Inoperative Community' (hereafter 'IC'), chapter one in The Inoperative Community, trans. Peter Connor et al (Minneapolis: University of Minnesota Press, 1991); hereafter IC. Martin Heidegger, Sein und Zeit, 16. edition (Tübingen: Max Niemeyer, 1986). Being and Time, trans. John Macquarrie and Edward Robinson, 13. edition (Oxford: Blackwell, 1995); hereafter BT. As is standard practice, all references here are to the marginal, original German pagination.

3. In response to which the character with whom the protagonist has this conversation, says: "Terrifying. Not that I know what you're talking about". The fortuitous eruption of the ontological fundaments of our existence into that existence is both incomprehensible and the object of anxiety.

4. In his Foreword to IC, Christopher Fynsk makes the crucial observation that “...the gesture of thought that animates [Nancy's] work...constitutes its true novelty and even its decisive importance for contemporary critical and philosophical thought" (viii), and he characterises this gesture as one of "returning to themes that play a crucial role in all discourses concerned with politics or the grounds of social existence but that have become abstract - the prey of ideology - by virtue of the fact that the philosophical presuppositions defining their meaning...have succumbed to the nihilism that inhabits them." (ix).

5. See BT $\S 26,122$, where we read about this kind of solicitude that it "takes over for the other that with which he is to concern himself. The Other is thus thrown out of his own position; he steps back so that afterwards, when the matter has been attended to, he can either take it over as something finished and at his disposal, or disburden himself of it completely."

6. A quite separate reason why this is redundant arises from the fact that Fynsk's Foreword to IC provides such a masterful, insightful, and finely judged reconstruction of these moves, and is therefore so much more than an Introduction to Nancy's text, that a less adept reader of Nancy (and of Heidegger and Blanchot) would end up cruelly exposed.

7. If such a broad characterisation as 'the thoughts of difference' may be applied to a trajectory within Western thought which encompasses - if not exclusively so - the writings of Heidegger, Blanchot, Bataille and Derrida, as well as other exponents of contemporary 'French' philosophy, where it is not a matter of a language, much less of a nationality, but of sopething like a philosophical sensibility. Many of the finest practitioners of 'French' philosophy belong geographically elsewhere.

8. For a more extensive discussion of the issues which concern us here, one would also, minimally, have to take into account Heidegger's later essays 'What is Metaphysics?' (1929), 'Of the Essence of Truth' (1930), and 'The Thing' (1950). But the present paper can only present these issues in a preliminary manner and leave the inclusion of these and other works into the discussion for another time.

9. Or, to give it its full title, 'Preliminary Sketch of the Existential-ontological Structure of Death'. This is the heading for BT $\S 50,249$.

10. Both the translations by Macquarrie and Robinson and by Stambaugh render 'unüberholbar' in a manner which seems unnecessarily ponderous to me, given the unusually 'straightforward' German term chosen by Heidegger. This is why I propose 'unovertakeable' instead of 'not to be outstripped' (Macquarrie and Robinson) and 'not-tobe-bypassed' (Stambaugh), although I use the less inelegant 'insurmountable' in less technical contexts.

11. This is why the translation of Befindlichkeit as 'state-of-mind' (Macquarrie and Robinson) has to be rejected out of hand. Stambaugh's translation of it as 'attunement' has the most unfortunate effect of eradicating the difference between Befindlichkeit and Gestimmtsein, which is similarly unacceptable.

12. To be precise, it should be pointed out, as Werner Marx does, that 'the nothing' (das Nichts) does not explicitly appear in Heidegger's oeuvre until after BT, namely in 'What is 
Metaphysics?' which "carries out the step from 'notness' [Nichtheit] or 'nullity" [Nichtigkeit] to 'the nothing' [Nichts]" (Marx, 1983, 92).

13. This section will begin to gesture towards this 'implication' which nonetheless, in a more profound sense than would admit of it merely being accomplished later on, remains to be thought.

14. It must be emphasised that this project has already been gestured towards in a number of recent texts, most notably in Françoise Dastur, Death: An Essay on Finitude, trans. John Llewelyn (London: Athlone, 1996), hereafter D; Jacques Derrida, Aporias, trans Thomas Dutoit (Stanford: Stanford University Press, 1993); Christopher Fynsk, Heidegger: Thought and Historicity (Ithaca: Cornell University Press, 1993), ch. 1; Werner Marx, Gibt es auf Erden ein Maß? (Hamburg: Felix Meiner Verlag, 1983); especially chapters 1 and 3; but none of them, in my understanding of them, quite makes the connections attempted here.

15. Is it going too far to suggest that implicitly Heidegger only accords the other a demise, not an authentic 'dying' as being-towards-death? If the latter possibility were to be admitted, the ontologically disclosive possibilities of the death of the other might be considered less remote within BT.

16. Both the translations by Macquarrie and Robinson and by Stambaugh render this sentence as "No one can take the other's dying away from him" which, whilst avoiding the Latinate origin of 'relieve', also loses the sense of a burden being lifted from the other in this apparent, false ambition. Hence my alternative suggestion.

17. Alphonso Lingis, The Community of Those Who Have Nothing in Common (Bloomington and Indianapolis: Indiana University Press, 1994).

18. Solitude does not mean individuality and least of all interiority. Heidegger calls solitude a deficient mode of being-with (BT $\S 26,120$ ).

19. Nancy formulates this as follows: “...compearance...consists in the appearance of the between as such: you and I (between us) - a formula in which the and does not imply juxtaposition, but exposition." ('IC' 29).

20. Heidegger writes: 'Death, as possibility, gives Dasein nothing to be 'actualized', nothing which Dasein, as actual, could itself be. It is the possibility of the impossibility of every way of comporting oneself towards anything, of every way of existing. [It] reveals itself to be such that it knows no measure at all, no more or less, but signifies the possibility of the measureless impossibility of existence.' (BT § 53, 262). And Françoise Dastur comments: 'Death is a distinctive possibility only if it presents Dasein with nothing to be realised, for it is the possibility of the absence of everything possible..., the possibility of the pure and simple impossibility of Dasein.' (D, 58) and, 'Death reveals itself....as pure possibility, which will never see itself annihilated by being realised...' (D, 59).

21. In his Foreword to IC Fynsk comes very close to suggesting the approach taken in this paper, for instance when he states that "The problem of death and community should be explored at much greater length and deserves a separate treatment...I believe that an attentive reading of Being and Time will suggest...that Dasein comes to know its mortality precisely by way of the other's relation to its death. It is through its assumption of mortality that Dasein first encounters the other - but Dasein knows its mortality only by way of the other and what the other communicates of its mortality." (IC xvi). Heidegger does indeed come very close to saying this (most notably in BT $\S 47,238 \mathrm{f}$ ), but then swerves away from the implications of this insight. But here it is not a question of uncovering how Dasein comes to know its own mortality - it seems to me that Heidegger's analyses of anxiety and anticipation already powerfully accomplish such an uncovering. It is rather a matter of showing that something like a reciprocal being-towards-death is that which, by affirming singularity and finitude, is constitutive of the being-in-common of knowingly finite beings.

Fynsk also observes that "if authentic being-towards-death is the condition of Dasein's knowing itself as existing..., then it must also be the condition of encountering the other: it 
is the opening of a relation at the same time that it is the tracing of a singularity. As Heidegger declares explicitly, Mitsein and Dasein are co-originary." (IC xvi). No doubt this approach is sustainable by a certain reading of BT, but it is not the approach taken here, where it is rather the reciprocal exposure to the death of the other that is constitutive of our Mitsein (especially in section III). And again, it seems to me that Nancy's aim in ' $\mathrm{IC}$ ' is to uncover this finite reciprocity as the ground of being-in-common, rather than to contribute further to an understanding of how each Dasein relates to its own finite existence.

22. Cf. BT § 31 on 'Being-there as Understanding', for the sense in which this term is being used here.

23. Another way in which these thoughts are 'unworkable' concerns the difficult question of their political efficacy. In his Foreword to IC Christopher Fynsk observes: '...anyone seeking an immediate political application of this thought of community risks frustration...it is exceedingly difficult to define how...one might move from [Nancy's] definition of a...differential articulation of social existence...to any currently existing politics...there is a point at which this move becomes properly unthinkable in the terms of any traditional conception of the relation between theory and practice: one cannot work to institute or realize this thought of community.' (IC xf).

24. "Being-alone is a deficient mode of being-with" (BT $\$ 26,120$ ).

25. It would, however, be fruitful to explore the temporality of being-in-common against the background of Heidegger's conception of the temporal-horizonal projection of Dasein's existence. But this would take us beyond the bounds of this paper.

26. See also, "Gesellschaft... has taken the place of something for which we have no name..." ('IC' 11); and, in "place of the subject - or on its reverse side - ...there is indeed 'something'...: our limit lies in not really having a name for this 'something' or for this 'someone"" ('IC' 25), given that the term 'Dasein' is too narrowly bound to one configuration of this being, we might add.

27. Don DeLillo, The Names, 138. The inclusion of this literary frame reminds us that the exchange of thought between Heidegger and Nancy does not take place in a closed economy but that this exchange is itself in dialogue with other (kinds of) texts. 